\title{
The Evolving Landscape of South-East Asian Higher Education and the Challenges of Governance
}

\author{
Sauwakon Ratanawijitrasin
}

\section{Introduction}

From the time the Association of South-east Asian Nations (ASEAN) was established over four decades ago, the South-east Asian region has experienced waves of rapid change when countries moved towards greater liberalization in their socio-economic activities and closer interdependence regionally and globally. Within this context, domestic and global forces have significantly transformed the region's higher education sector.

The introduction of ASEAN Community scheduled for 2015 is a regionalization push that arrives on top of existing changing trends that have shifted the landscape of higher education in South-east Asia (SEA). On the eve of the upcoming regional integration, ASEAN member countries face new challenges in their higher education sector-increased competition, needs for harmonization, and demands for human resources with knowledge and skills to thrive in a new and more integrated socio-economic context.

This paper aims to (1) provide an overview of the changing trends in and development of higher education sector in SEA, (2) describe key policy initiatives and current state of higher education governance focusing on higher education institutions, (3) review key efforts towards regional integration, and (4) identify challenges facing the region higher education sector and key policy questions.

\footnotetext{
S. Ratanawijitrasin $(\bowtie)$

Faculty of Social Sciences and Humanities, Mahidol University, Mahidol, Thailand

e-mail: sauwakon.r@gmail.com

(C) The Author(s) 2015
}

A. Curaj et al. (eds.), The European Higher Education Area,

DOI 10.1007/978-3-319-20877-0_15 


\section{The Changing Landscape of Higher Education in South-East Asia}

The past two decades witnessed significant change in SEA higher education sector - both on the demand and supply sides, as well as the national and institutional levels. Changes in higher education governance and finance have taken place within a broader shift in social, economic, and political context. Four major trends have characterized changes in higher-education landscape of South-east Asia: massification, diversification, marketization, and internationalization.

\subsection{Massification}

With rapid economic development and globalization drawing larger proportion of the population into labour market and driving demand for workforce with broader knowledge and skills and more technical capability, not only larger number of people seek higher education, but they also look for a wider range of options in higher education. This has led to a massive increase in the number of students going into higher education, which then resulted in the supply-side response to boost the number and variety of higher education institutions (HEIs) and academic programs. The increased supply, in turn, generates greater opportunities of access with greater number of slots and availability of options in higher education, in a reinforcing feedback loop.

The mass access to higher education is apparent in the explosion of the number of students and HEIs. Examples can be found in countries throughout the region.

In Cambodia, the number of students in higher education has jumped from around 10,000 in the 1990 s to over 250,000 by 2014 . Today most of them are self-pay students (Mak and Un 2014). Its neighbouring Lao PDR has seen its number of students studying in public HEIs increase from 4980 in 1994 to 91,713 in 2013. During this period, the number of students in private HEIs rose from 0 to 19,621 (Mitaray 2013). Although the rising rate in student population is less dramatic in Thailand, it is no less significant. The country's higher education students numbered 1.07 million in 2000, and doubled to 2.12 million in 2013 (NSO 2000; Sirisamphan 2014). In Indonesia-South-east Asia's largest country-students number rose from 4.4 million in 2008 to 5.8 million in 2014 (Sailah 2014; Varghese and Martin 2013).

On the supply side, a key driving force of the expansion of higher learning is government policy response to the demand pressure. Governments not only expanded public HEIs, but in those countries where private HEIs were non-existent, they also opened up the sector for private and overseas operators.

This trend is most obvious in the Greater Mekong sub-region countries. The number of higher education institutions in Lao PDR, for example, have increased from 10 (all government-owned) in 1994 to 141 (62 government and 
79 privately-own) in 2013 - a 14 times increase in two decades (Mitaray 2013). Cambodia has also witnessed a similar trend in its higher education sector. In 1994, there were only 8 public HEIs with no private institutions; but by 2014 the number of private HEIs becomes 66, surpassing the also growing number of public HEIs which stand at 39 in the same year (Mak and Un 2014). The public and private HEIs combined to a total of 105 institutions, an increase of over 8 times in 20 years. In Thailand, with the transformation of 40 teacher colleges and 9 technical colleges into universities in 2004 and 2005 respectively, the number of its public universities jumped from 27 to 76 within two years. The establishment of two additional new public universities brought the number of public institutions up to 78 by the end of 2005. Many private HEIs have also been introduced in the past two decades, which added up to a total of 144 HEIs - public and private - in 2012 (calculated from OHEC 2012). The number of HEIs in Vietnam more than quadrupled between 1987 and 2011. In 1987 there were only 101 HEIs, with 63 universities and 38 colleges (Thinh and Phuong 2011); by 2011, the number of total HEIs became 414, consisting of 188 universities and 226 colleges in 2011. Among those universities, 138 are public and 50 private (Huong 2011). Myanmar has also seen a tremendous expansion of HEI's in recent years, from 32 in 1988 to currently 169 (Thein 2014).

Even countries with very few HEIs two decades ago have seen the number of HEIs jumped significantly. Singapore government, in a strategic move, added three new public universities in 2000s, which more than doubled the number of its publicly-funded autonomous universities - from 2 to 5. Similarly, higher education expansion in Brunei Darussalam was also clearly policy-led change. Of the country's 4 public universities, 2 were founded in the 1980s and the other 2 in the 2000s.

\subsection{Diversification}

The expansion of higher education in the region has been accompanied by diversification of the sector in terms of types of providers, types of academic programs, institutional arrangements, as well as modes of delivery.

The shift in higher education landscape in many countries from an entirely or pre-dominantly public sector to one with ever increasing share of private sector providers is probably the most apparent change. The mushrooming of private HEIs has offered the population with much greater opportunity of access and diversity of choice.

The emergence of cross-border providers, made possible by the General Agreement on Trade in Services (GATS), adds to the increase in variety of higher education options. For example, Monash University from Australia and Newcastle University have opened branch campuses in Malaysia; RMIT University-also from Australia - operates an overseas campus in Vietnam. Another cross-border provider is British University Vietnam, which is supported by a consortium of universities in the UK, providing generally the same courses as offered in the home universities in the UK (Tuan 2012). Singapore hosts the Asian campuses of several 
world-class universities such as INSEAD, University of Chicago Booth School of Business, Digipen Institute of Technology, Germany Institute of Science and Technology (Lim 2012).

New arrangements are also made available on the program front. There are collaborations between HEIs in South-east Asia, with one or more HEIs outside, as well as within the region, to jointly offer a wide range of programs. Academic arrangement of these programs, as well as the terms used to call them, vary widely. There are joint degree programs, double/dual degree programs, sandwich programs, twinning/partnered programs, to name some.

In terms of modes of delivery, although the majority of education providers still rely on traditional methods of teaching and learning, a few online programs have emerged. These are programs that cater to popular demand, such as distant MBA programs offered by some HEIs in Malaysia, Singapore, and Thailand (mbastudies. com 2014).

\subsection{Marketization}

Three key factors have led higher education sector in South-east Asia in general to be more market oriented - the increase of private for-profit providers, the increase in autonomy of public HEIs coupled with the needs to partially self-finance, and the need of HEIs to compete for students, academic staff, and resources amidst the environment of enormous supply growth.

Marketization in higher education is more a topic of controversy than of comprehensive study. Concerns have been raised about many potential adverse effects of higher education marketization, particularly on the possible deviation of HEIs from providing access to quality education, commercialization of public properties, shifting away from unprofitable but necessary courses, and shifting personnel time from required education to profitable activities.

\subsection{Internationalization}

All countries in the region have made efforts at national and institutional levels to internationalize. Student mobility, faculty mobility, international program and academic collaboration are current dominant modes of internationalization.

One objective for internationalization efforts is to expose local students to international knowledge and experiences. Student exchange is common and expanding throughout the region. The majority of student mobility programs are bi-lateral arrangements; there are also a few multi-lateral programs. Many HEIs have internationalized their programs/curriculum. For example, Vietnamese government funds selected universities to develop "Advanced Curriculum" in partnership with overseas universities for local students, with English as the medium of 
instruction (Tuan 2012). University Brunei Darussalam encourages its undergraduate students to broaden experience abroad during its required Discovery Year (Aziz 2012). Universities in Singapore provide international internships and international research programmes in an effort to prepare students for the global workplace (Lim 2012).

Another objective is to attract foreign students. This is the reason why a large number of HEIs offer "international programs" which are mostly taught in English. Some countries are more proactive in attracting foreign students. The Ministry of Education Malaysia has established Education Malaysia Global Services as the official gateway to promote Malaysia as a global destination for education, manage international student applications, managing information, and facilitate processes (EMGS 2014).

A few universities from the region also establish offshore presence. For example, the National University of Singapore has established the NUS-Suzhou Research Institute in China (Lim 2012).

\section{Restructuring Higher Education and the New Modes of Governance and Finance}

Traditionally, the higher education sector in all SEA countries was mostly small, inward-looking, with government playing a significant role. The vast majority of HEIs in each of the countries were government-owned; private HEIs were few or non-existent in some countries. Not only governments owned and funded HEIs, they also operated them as government agencies, exerted direct control over policy and procedural matters.

This pattern has changed in the recent past as the massification trend swept the higher education sector. The expansion and diversification of the system have caused tension to the traditional model of higher education. Governments can no longer keep up with increasing demands to provide free or highly subsidized education; new ways of financing and additional financial resources must be sought to meet the expansion.

In addition to enlarging the number of HEIs, another key policy has focused on responding to challenges of governance and finance. Most governments have shifted from a direct control approach to a regulatory approach by transferring certain policy, and operating authority and responsibility to state-owned higher education institutions in the form of increased institutional autonomy. Two general approaches to institution restructuring have been employed-(1) by transforming universities from a bureaucratic government agency to an autonomous body and (2) by granting greater authority on certain operational matters to universities, while retaining them as government agencies. The level of university autonomy varies among the countries, from Singapore with highly independent universities to a centralized system in Myanmar. Thailand and Indonesia have a mixture of public autonomous, government-managed, and private universities. 
From the experiences of higher education development in South-east Asia, five observations can be made on the variations in the way reforms have taken place in different countries, which reflect the diversity in the essence and process of change.

First, reforms arrived at different times in different countries, depending on the socio-economic readiness and sometimes with clear link to the national political direction. For example, in Vietnam the doi moi reform started in 1986 subsequently pushed a significant expansion and development in the country's higher education as part of the policy to boost human resources for economic development. In Myanmar, the recent introduction of greater openness in its political system, following its general election in 2010, is bringing a new sense of urgency to reform its higher education sector, which has placed a number of restructuring plans on the policy drawing board.

Second, the pace of change also differs greatly. Some significant policy shifts take longer, while others happen more swiftly, even within the same country. For example, the move to transform teacher colleges and technology colleges into universities in Thailand in the mid-2000s was brief compared to the attempts to convert its public universities into autonomous organizations. The ease of change for the former was due to the fact that the legislation changed the colleges' organization status, and by extension the status of their personnel upgrading them from college to university, while keeping the status quo of the personnel as government employees. By contrast, the attempts to create autonomous universities faced far greater degree of bureaucratic resistance, as the initiative at the time demanded that the civil servants be converted to contract university employees, depriving them of the job security and benefits associated with government officer status.

Direction of change sometimes proceeds in twists and turns. The reform in Indonesia presents an example of this third observation. An Indonesian Government Regulation was issued in 1999 which provided the legal basis for selected public universities to become non-profit "legal entities." The status of seven public universities was changed into this class and became "State Owned Legal Entity (SOLE) Universities", with their own governing board and authority for major administrative and academic decisions. According to the reform plan, all university staff would become university employees instead of civil servants, as they formerly were. In 2008, the Law on Education as a Legal Entity was passed by the Parliament to expand this reform to the entire university sector. All public and private universities would become autonomous "educational legal entities" by 2012 and 2014 respectively. However, this new Law was revoked in 2010 by the Constitutional Court. In response, the government then issued a new regulation concerning the status of the university, returning each to a state university as a government agency under the direction of the Department of National Education. Then in 2012, the House of Representatives enacted the Higher Education Law allowing universities that met "Financial Management Code" to become "Public Service Agency" with conditional autonomy on financial management. Subsequently, in 2013, the government changed the status of seven public universities from "Public Service Agency" to a "Public University-Legal Entity," similar to SOLE (Kusumadewi and Cahyadi 2013; Varghese and Martin 2013). 
Thailand provides another example of a long and winding process of change. The initiative to transform public universities, with the legal status as government departments, into autonomous organizations was proposed as early as 1964 . A proposal was approved in principle by the cabinet in 1974 , but was met with resistance from many universities. In 1991 the Cabinet submitted Bills to transform 16 out of the 20 public universities at the time into autonomous entities. The attempt again failed. Due to strong resistance, the idea had not been materialized until a condition set by an Asian Development Bank (ADB) loan agreement gave the policy a new momentum. In 1998, because of the need for financial injection to ease an economic crisis, Thai government sought help from international organizations. The ADB loan agreement set clear conditions for Thailand to transform all of its public universities into autonomous ones by 2002, with at least one university to change within the year the agreement was signed. Since the levels of resistance to change differed among the universities, the course of action taken then was to allow each university to manage its own academic community to determine when it would be ready for transformation. In 1998, one university was converted to autonomous status, fulfilling the initial requirement set by the ADB loan. However, it took another decade to achieve the transformation of the next public university. Between 2007 and 2008, seven more public universities became autonomous. The rest have remained government agencies until today (OHEC undated; 2012).

Forth, within a country, changes brought about by reforms have not always taken place across the board. This is apparent in a number of countries. While Singapore government has adopted policy to transform, and to form all public universities to be autonomous entities, many other countries have decided to start with a small, selected number of universities.

The Singapore Management University was established as the country's first autonomous government-funded university in 2000 (SMU 2014). Five years later, the Singapore Government moved to transform the other two existing universities - National University of Singapore (NUS) and Nanyang Technology Universityinto autonomous institutions (Ministry of Education, Singapore 2005). These two universities were then corporatized in 2006, into not-for-profit, autonomous organizations registered as company limited.

Some countries chose to give a selected few of their HEIs - those with adequate capacity and potential - the autonomy first, rather than across the board structural change. That means that, while some HEIs are allowed more authority to make policy decisions, the remaining continue to operate in the traditional way-within bureaucratic management. For example, in Cambodia, a 1997 Royal Decree granted increased autonomy to selected higher education institutions by giving them special status as Public Administrative Institutions (PAI) with the expectation to increase administrative efficiency in a resource constrained situation. Indonesia, in the 1999 policy initiative described above, also converted a few selected public HEIs into autonomous bodies as pilot institutions (Varghese and Martin 2013). 
Finally, the focus and extent of these changes differ as well. Reforms in different countries have focused on different areas, and allowed different levels of autonomy. Some changes are substantial, while others are more procedural. Autonomous universities generally enjoy greater freedom in setting their own policies, managing finance and human resources, as well as determining academic structures, programs and courses.

As the general trend of higher education reforms in all the SEA countries involves movement towards granting greater autonomy to HEIs, the discussion in this section focuses on the governance structures of the new forms of HEIs, and the scope and level of institutional autonomy. Four key areas of autonomy are discussed below with examples from different countries in the region-governance structures, finance and budget, personnel management, and academic matters.

\subsection{Governance Structures}

Devolution of authority from the state to the institution normally comes with creation of two dominant features in the HEI's structural arrangements: a stronger executive and a new governing body. Reforms generally resulted in the shift of the highest decision-making body from the relevant ministry overseeing the HEI to a governing board of the individual institution.

Governing boards are called differently in different countries, for example, board of trustees, board of directors, board of regents, and university council. The roles, authority, composition, and the process for appointing board members vary as well. Examples from general characteristics of governing boards in the three countries below demonstrate the range of such variations.

Public universities in Singapore are registered companies and are run as corporate entities. They are probably endowed with the greatest autonomy compared to their peers in the region. The boards of trustees are generally composed of significant proportion of members from the non-governmental sectors, such as business leaders, academics, and professionals, which are drawn internationally. Board members are appointed by the Minister for Education, and are charged with key responsibilities to chart the institution's directions, oversee and safeguard its funds and assets, develop initiatives for its advancements, and select and appoint the university president, as well as deans and directors.

Each public university in Thailand - autonomous and non-autonomous - has a university council as its highest governing body. A university council nominates its own members and chairperson, who is officially appointed by the King. Members of university council generally comprise of representatives from the university executives, faculties, government agencies, and external experts. It's a general tendency for Thai universities to include prominent retired government officers and academics on their councils. Many universities also appoint a few (normally one or two) business leaders as council members. University Council is responsible for setting policy and internal regulations, approve academic programs, supervising 
academic quality, and monitoring and evaluation. The council also selects the university president (also with the King's official appointment) who is accountable to the council. Other university executives, such as deans and directors of the units in the university, are also appointed by the university council.

In Cambodia, members of the governing board in a PAI university are appointed by the government. From the HEI side, the rector and a faculty staff representative are seated on the board; other board members are officers from various ministriesparticularly the parent ministry of the HEI and the Ministry of Education, Youth and Sport (MoEYS), and other stakeholders such as donors. The board composition from a university can serve as example: on the board of trusties are representatives from the Ministry of Health, Ministry of Council of Ministers, MoEYS, Ministry of Economics and Finance. The board of trusties is responsible for monitoring and approving the HEI's development plan and finance, determining the number of personnel and defining structure and roles of subordinated units. The appointment of the university rector is made by royal decree, following the request of the Prime Minister proposed by the Minister of the HEI's parent ministry. Vice rectors and deans are appointed by the prime minister, while the ranks of vice deans and department chairs are appointed by the parent minister (Royal Government of Cambodia 2001; Varghese and Martin 2013; You Virak, personal communication, 12 March 2015).

\subsection{Finance and Budget}

Governments continue to fund HEIs which have been given greater autonomy or corporatized, with two important changes related to the finance of the institution. First, the method of government budget allocation changes from line-item budget to a lump-sum budget or block grant, and HEIs are given greater authority over its use; second, the HEIs are allowed to generate their own revenues. Besides government subsidy, other sources of finance for HEIs with autonomy include tuitions, self-generated revenues, and donations. HEIs in some countries, such as Cambodia, also receive financial support from international donors.

Authority over financial decisions among these HEIs varies. Generally, HEIs can fully determine the use of self-generated funds; however, different governments allow different levels of authority over the use of government budgets. Autonomous HEIs in Thailand, Singapore and Indonesia have full autonomy over finance and budget - on both the funds generated by HEIs and those allocated by the government. By contrast, PAIs in Cambodia are allowed to keep and manage self-generated funds, but need ministry's approval for important decisions to use the government budget (ADB 2012; Varghese and Martin 2013; Sam Nga, personal communication, 14 September 2014).

There are a variety of ways these HEIs raise funds, for example, offering degree programs and training courses which are in high demand, partnering with private HEIs in "franchise programs", raising tuition fees, seeking research grants, 
commercialization of innovations, conducting consultancies, turning university properties into business facilities, and entering into business ventures.

\subsection{Human Resource Management}

Autonomy over human resource management is a controversial area in higher education governance reform. The issue regarding whether HEI's staff are required to change their status from civil servants to university employees in particular was a cause which slowed down reform in some countries. A system of dual-track personnel management has been employed to allow for smoother reform.

Two systems of personnel co-exist in Thai autonomous universities, for example. At the time of institution restructuring, but not later, public university personnel who are civil servants are allowed to choose whether to become university employee or continue the status of civil servant. The rules governing personnel management differ between the groups. The government promulgated a specific law - the Regulation of Civil Servants in Higher Education Institutions Act for the latter group. Salaries and remunerations for personnel in the first group are set by the university and are tied to performance, while salaries for those in the second group follow the civil service system. Although the salary levels, increments, and benefits for the two groups follow different rules, both groups are subject to university's performance requirements. In Vietnam, a Ministry of Education and Traning's Resolution on Innovation in Higher Education issued in 2010 grants presidents/rectors of HEIs the authority to determine the pay scale for faculties in accordance with their contributions. However, HEIs are to determine staff recruitment, assignment, and transfer, based on the approved annual personnel plan or report the decisions to the ministry (Thinh and Phuong 2011).

\subsection{Academic Matters}

Where authority to determine academic programs and courses lies depends on whether a decentralized or central planning approach is used as the basis of education system design. In systems where HEIs are given high level of autonomy, the final decision for the approval of academic programs rests within the university (Singapore and Thailand for example). In others, government provides the framework or set priority for academic program development (Vietnam and Cambodia for example). By contrast, in countries relying heavily on central planning, the government determines which programs and courses the HEIs are to deliver (Mayanmar for example) (Table 1). 


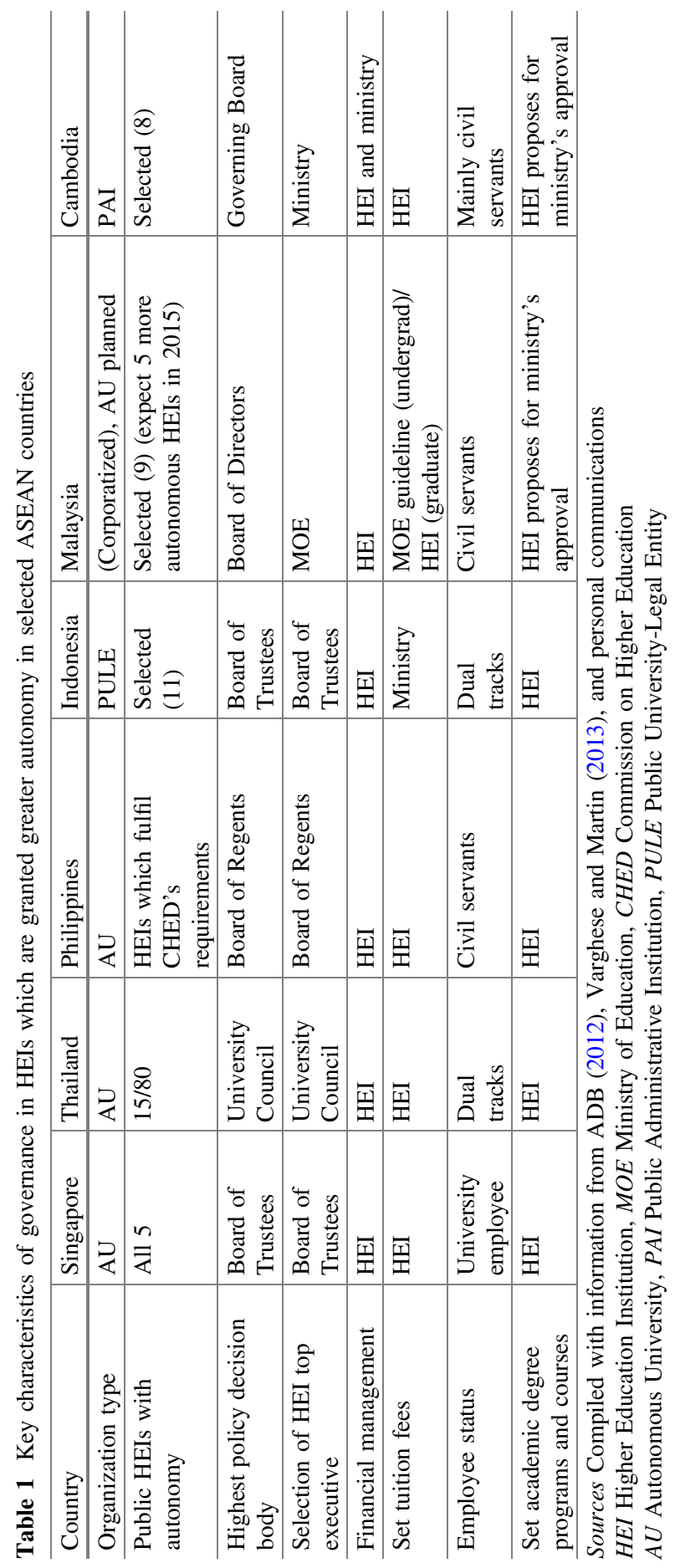




\section{Quality Assurance}

The high wave of expansion in the number of HEIs in all the countries throughout the region, particularly the vast increase in private and cross-border providers, coupled with the devolution of government control to public universities have raised concerns over the quality of education these institutions provide amidst fiercer competition and financial constraints. Governments have responded by issuing new rules and oversights, as well as new structures for quality assessment. Systems of quality assurance have been introduced by all the countries, with evident differences.

In all ASEAN member countries, with the exception of Myanmar, governments have established national quality assurance agencies as the policy arm to ensure quality of higher education. This represents a general trend to place the oversight authority for higher education quality with a specialized national organization, and to entrust a process of external peer review for quality assurance.

Efforts to introduce an external mechanism to assess quality of higher education existed in SEA as early as the 1950s. The oldest established agency dealing with quality assurance in the region is the Philippine Accrediting Association of Schools, Colleges and Universities-PAASCU—established in 1957. PAASCU is a private, voluntary, non-profit corporation, which continues to play an active role in certifying the quality levels of accredited programs for private HEIs today.

Systematic government intervention to build a national organization for the purpose of assessing higher education quality has been a relatively recent phenomenon, however. Brunei Darussalam National Accreditation Council (BDNAC), the Philippines' Commission on Higher Education (CHED), and Indonesia's Badan Akreditasi Nasional-Perguruan Tinggi (BAN-PT) were established in the 1990s. Other national quality assurance bodies in the region-Thailand's Office for National Education Standards and Quality Assessment (ONESQA), Singapore's Higher Education Quality Assurance Section (HEQA) and Council for Private Education (CPE), Vietnam's Education Testing and Accreditation (ETA), Accreditation Committee of Cambodia (ACC), Malaysian Qualifications Agency (MQA), and Lao PDR's Educational Standards and Quality Assurance Centre (ESQAC) - were all introduced during the following decade (SEAMEO RIHED 2011).

Myanmar does not currently have a national external quality assurance system. Councils within individual universities are responsible for the institution quality assurance. The Minister for Education formally chairs these Councils.

The names, years established, and key characteristics of the QA agencies in South-east Asia are summarized in Table 2. 
Table 2 Structural characteristics of external quality assurance agencies in South-east Asian countries

\begin{tabular}{|c|c|c|c|c|}
\hline Country & Agency & Founded & $\begin{array}{l}\text { Type of } \\
\text { organisation }\end{array}$ & Finance \\
\hline $\begin{array}{l}\text { Brunei } \\
\text { Darussalam }\end{array}$ & $\begin{array}{l}\text { Brunei Darussalam } \\
\text { National } \\
\text { Accreditation } \\
\text { Council (BDNAC) }\end{array}$ & 1990 & $\begin{array}{l}\text { Centralised } \\
\text { government } \\
\text { Agency }\end{array}$ & Government \\
\hline Cambodia & $\begin{array}{l}\text { Accreditation } \\
\text { Committee of } \\
\text { Cambodia (ACC) }\end{array}$ & 2003 & $\begin{array}{l}\text { Independent } \\
\text { Public } \\
\text { Authority }\end{array}$ & Government + HEIs + donors \\
\hline Indonesia & $\begin{array}{l}\text { Badan Akreditasi } \\
\text { Nasional-Perguruan } \\
\text { Tinggi (BAN-PT) }\end{array}$ & 1994 & $\begin{array}{l}\text { Independent } \\
\text { Public } \\
\text { Authority }\end{array}$ & Government \\
\hline Lao PDR & $\begin{array}{l}\text { Educational } \\
\text { Standards and } \\
\text { Quality Assurance } \\
\text { Centre (ESQAC) }\end{array}$ & 2008 & $\begin{array}{l}\text { Centralised } \\
\text { Government } \\
\text { Agency }\end{array}$ & Government \\
\hline Malaysia & $\begin{array}{l}\text { Malaysian } \\
\text { Qualifications } \\
\text { Agency (MQA) } \\
\end{array}$ & 2007 & $\begin{array}{l}\text { Independent } \\
\text { Public } \\
\text { Authority }\end{array}$ & Government + HEIs \\
\hline Myanmar & - & - & - & - \\
\hline \multirow[t]{3}{*}{ Philippines } & $\begin{array}{l}\text { Commission on } \\
\text { Higher Education } \\
\text { (CHED) }\end{array}$ & 1994 & $\begin{array}{l}\text { Centralised } \\
\text { Government } \\
\text { Agency }\end{array}$ & Government + HEIs \\
\hline & $\begin{array}{l}\text { Certifying Bodies:- } \\
\text { Federation of } \\
\text { Accrediting } \\
\text { Agencies of the } \\
\text { Philippines (FAAP) }\end{array}$ & 1977 & $\begin{array}{l}\text { Umbrella } \\
\text { Agency of } \\
\text { Certifying } \\
\text { Bodies for } \\
\text { Accredited } \\
\text { Programs in } \\
\text { Private HEIs }\end{array}$ & HEIs \\
\hline & $\begin{array}{l}\text { National Network of } \\
\text { Quality Assurance } \\
\text { Agencies (NNQAA) }\end{array}$ & 1957 & $\begin{array}{l}\text { Umbrella } \\
\text { Agency of } \\
\text { Certifying } \\
\text { Bodies for } \\
\text { Accredited } \\
\text { Programs in } \\
\text { Public } \\
\text { Universities }\end{array}$ & HEIs \\
\hline \multirow[t]{2}{*}{ Singapore } & $\begin{array}{l}\text { Higher Education } \\
\text { Quality Assurance } \\
\text { Section (HEQA) }\end{array}$ & 2001 & $\begin{array}{l}\text { Centralised } \\
\text { Government } \\
\text { Agency }\end{array}$ & Government \\
\hline & $\begin{array}{l}\text { Council for Private } \\
\text { Education (CPE) }\end{array}$ & 2009 & $\begin{array}{l}\text { Statutory } \\
\text { Board }\end{array}$ & Government \\
\hline
\end{tabular}


Table 2 (continued)

\begin{tabular}{l|l|l|l|l}
\hline Country & Agency & Founded & $\begin{array}{l}\text { Type of } \\
\text { organisation }\end{array}$ & Finance \\
\hline Thailand & $\begin{array}{l}\text { Office for National } \\
\text { Education Standards } \\
\text { and Quality } \\
\text { Assessment } \\
\text { (ONESQA) }\end{array}$ & 2000 & $\begin{array}{l}\text { Independent } \\
\text { Public } \\
\text { Authority }\end{array}$ & Government \\
\hline Vietnam & $\begin{array}{l}\text { Education Testing } \\
\text { and Accreditation } \\
\text { (ETA) }\end{array}$ & 2003 & $\begin{array}{l}\text { Centralised } \\
\text { Government } \\
\text { Agency }\end{array}$ & Government + HEIs \\
\hline
\end{tabular}

Source Compiled from information presented in SEAMEO RIHED (2011)

\section{Regional Integration and the Efforts on Higher Education Harmonization}

The move towards regional integration - the ASEAN Community-in 2015 adds another important dimension to the ongoing changes in South-east Asian higher education sector.

In the ASEAN framework of integration founded on 3 pillars, education is considered a component in the Socio-Cultural Pillar of ASEAN Community. Key ASEAN policy documents on education-the ASEAN Socio-Cultural Community Blueprint issued in 2009, the Declaration on Strengthening Cooperation on Education signed in 2009, and the 5-Year Work Plan on Education (2011-2015) — do not include specific policies on higher education (ASEAN 2009a, b, 2012). The items contained in these documents that appear relating to higher education are general statements which involve promoting greater mobility of students and skilled workers, developing skills framework and common standard of competencies, and establishing ASEAN educational research convention to promote collaborative R\&D; they are listed without indication on specific mechanisms to achieve them. On the economic arena, however, concrete regional initiatives with implications on higher education exist in the form of mutual recognition arrangements (MRAs). Between 2006 and 2012, ASEAN member states have signed seven MRAs to facilitate flows of professional and other services to improve the efficiency and competitiveness of the ASEAN Economic Community. These MRAs cover engineering services, architectural services, surveying qualifications, accountancy services, nursing services, medical practitioners, dental practitioners and tourism professionals. The need to establish standards and requirements, and to set up infrastructures for certification and accreditation of these professional fields for mutual recognition will have significant implications on curricular of the related academic disciplines.

Although it appears that on the eve of ASEAN integration, a clear vision and concrete collective actions for the harmonization and development of regional 
higher education remain absent from the Association's official policy priorities, individual member countries have introduced policies in the direction of harmonization.

Recently, governments in three countries have separately taken steps to revise or restructure their higher education systems to bring their systems closer to other members of ASEAN. The biggest change is the Philippines education system reform in 2012. The government added 2 more years to its secondary education to form a new "K to 12 " system, so that the number of years for secondary school is in line with other ASEAN countries. Also in 2012, Myanmar introduced a credit system into their higher education. In Thailand, starting in 2014, universities have shifted the beginning of academic year from June to August. These changes mean significant steps forward for enhancing student mobility and contributing to efforts on building regional system for academic credit transfer and mutual recognition.

Meanwhile, a vast number of HEIs have reached out across borders in the region to forge closer ties, mostly by more extensive exchanges.

On the multi-lateral level, three regional bodies have carried out programs to facilitate greater integration. ASEAN Quality Assurance Network (AQAN), a network of national quality assurance agencies from ASEAN member countries, has developed regional quality assurance framework for higher education to serve as a common reference point for national QA systems. The South-east Asian Ministers of Education Organization-Regional Centre for Higher Education and Development (SEAMEO RIHED), an international organization under the direction of South-east Asian Ministers of Education Council, has promoted the idea for creation of an ASEAN higher education common space. It manages a multi-lateral student mobility program and proposes an Academic Credit Transfer for Asia (ACTFA). Another entity is ASEAN University Network (AUN), which is a network of 30 universities from ASEAN member states, operating student exchange program among its member universities and partners, with an ASEAN Credit Transfer System (ACTS). Of these three regional organizations, only AUN is within the jurisdiction of ASEAN.

\section{Reform, Regionalization, and the Challenges for Future Development}

The enormous changes and the imminent regional integration have presented South-east Asian higher education with great opportunities as well as challenges.

South-east Asia higher education development over the past two decades has taken the directions of expansion, liberalization, and restructuring. Restructuring will continue to be a key policy effort in many countries. As regionalization will soon take effect, harmonization and mutual recognition will and should be the main focus of regional higher education policy in the next two decades. 
At the national level, liberalization, and restructuring have made the region's higher education sector more diverse today in terms of governance and finance. In many countries, the scene of a relatively homogenous higher education sector entirely or predominantly populated with HEIs that were government agencies, funded solely with government budget, has shifted to one with a mixture of traditional public HEIs, public autonomous HEIs, private HEIs, and branches of overseas HEIs, financed by a mixture of sources. Even among the group of autonomous HEIs, diversity also exists in the structure and function of their governing boards. An obvious structural variation is the selection and composition of board members, particularly the proportion of external members from government and business sectors. National policy-makers face with a multitude of challenges. For instance, which paths or processes are to be taken to forge successful reform and manage transition; which are the effective policies and governance model(s), for their specific national contexts, to grant autonomy and capacity to HEIs, while maintaining oversight to ensure that the directions of autonomous HEIs continue to align with national strategic objectives and that they use public funds accountably. Also there are broader policy questions regarding the impacts of governance reforms and the performance of higher education systems on societal objectives, for instance, equity of access, quality of education, relevance and responsiveness of academic programs to the emerging knowledge and skill requirements, competency of the graduates to work in a world that is more interdependent regionally and globally.

At the institutional level, HEIs in the region face the new challenges of greater competition amidst the constraints of limited capacity and the need to be more self-reliant. HEI executives and board members need to find effective and efficient models to build capacity for teaching and research, produce innovations, attract students, generate revenues, internationalize, as well as enhance the HEI's standing locally and internationally.

At the regional level, there are currently multiple, yet non-coherent and sometimes overlapping efforts conducted separately to harmonize the region's higher education. This shows the sector's broad awareness and interest in regional collaboration to prepare for a more integrated future. It also indicates a need to find ways for the multiple stakeholders to work together in a coherent and coordinated process. South-east Asia can draw from the extensive experience of Europeespecially the Bologna process - to develop its own systematic and collective actions towards a regional higher education area. In particular, experience from Europe is valuable for SEA in managing a shared process to harmonize the diverse systems to create a regional higher education area where borders will no longer be barriers for academic mobility, credits and qualification recognition. The way forward for the regional integration requires that harmonization and creation of a regional common space in higher education be made a central policy priority of ASEAN, with a more systematic approach and concrete collective actions built around common regional goals. 
Acknowledgements Many people have provided and/or verified information to connect the dots which help form a comprehensive picture of South-east Asian higher education sector. I appreciate the help from Li Zhe, Dzulkifli Abdul Razak, Morshidi Sirat, Iwan Setiawan, You Virak, Sam Nga, and Dao Hien Chi. I also would like to thank Liviu Matei for his support.

Open Access This chapter is distributed under the terms of the Creative Commons Attribution Noncommercial License, which permits any noncommercial use, distribution, and reproduction in any medium, provided the original author(s) and source are credited.

\section{References}

ASEAN. (2009a). ASEAN socio-cultural community blueprint. Jakarta: ASEAN.

ASEAN. (2009b). Cha-Am Hua Hin declaration on strengthening cooperation on education to achieve an ASEAN caring and sharing community. Jakarta: ASEAN.

ASEAN. (2012). ASEAN 5-year education work plan 2011-2015. Jakarta: ASEAN.

ADB, Asian Development Bank. (2012). Administration and governance of higher education in Asia: Patterns and implications. Manila: ADB.

Aziz, S. W. S. A. (2012). Internationalization of higher education in Brunei Darussalam. Paper presented at the Country paper presented at the SEAMEO RIHED Seminar, Manila, The Philippines.

EMGS, Education Malaysia Global Services. (2014). About Us. http://www.educationmalaysia. gov.my/about-us. Accessed October 1, 2014.

Huong, N. T. L. (2011). University research management in Vietnam. Paper presented at the Country paper presented at the SEAMEO RIHED, Seminar on University Research Management, 16 September, Mandalay, Myanmar.

Kusumadewi, L. R., \& Cahyadi, A. (2013). The crisis of public universities in Indonesia today. Blog of the International Sociological Association, Retrieved June 29, from http://www.isasociology.org/universities-in-crisis/?p=1010. Accessed October 3, 2014.

Lim, K. M. (2012). Internationalisation of higher education. Paper presented at the Country paper presented at the SEAMEO RIHED, Seminar on Internationalization of Higher Education in Southeast Asia, 22 September, Manila, The Philippines.

Mak, N., \& Un, L. (2014). Linkage and cooperation between the higher education institutions and Industries: A Snapshot from Cambodia. Paper presented at the Country paper presented at the SEAMEO RIHED Seminar on Linkages and Collaboration between Higher Education Institutions and Industry, 16 September, Danang, Vietnam.

Ministry of Education, Singapore. (2005). NUS, NTU, SMU to become Autonomous Universities. Press release 12 April. http://www.moe.gov.sg/media/press/2005/pr20050412.htm. Accessed October 9, 2014.

Mitaray, S. (2013). Institutional restructuring of higher education in Lao PDR. Paper presented at the UNESCO-IIEP and SEAMEO RIHED Workshop on Institutional Restructuring in Higher Education, 23-26 July, Luang Prabang, Lao PDR.

NSO, National Statistics Organization, Thailand. (2000). Number of Students in Government and Private Institutions by Level of Education. http://service.nso.go.th/nso/nso_center/project/ search/result_by_department-th.jsp. Accessed October 2, 2014.

OHEC, Office of Higher Education Commission, Thailand. (2012). Annual report.

OHEC, Office of Higher Education Commission, Thailand. (undated) Transformation to Autonomous University: Past to Present. http://legal.tu.ac.th/tu_51/tu_control/pdf. Accessed June 25, 2012.

Royal Government of Cambodia. (2001). Sub Decree on the Establishment of University of Health Sciences as Public Administrative Institution, No: 127 ANK.BK Unofficial Translation 
JICA-HRD Project. http://www.moh.gov.kh/files/Legal\%20Document/Sub\%20Decree/Sub\% 20Decree $\% 20$ on $\% 20$ Establishment $\% 20$ of $\% 20$ University $\% 20$ of $\% 20 H$ ealth $\% 20$ Sciences $\% 20$ as \%20Public\%20Adminstrative\%20Institution_Eng.pdf. Accessed October 3, 2014.

Sailah, I. (2014). University-industry linkage in Indonesia. Paper presented at the Country paper presented at the SEAMEO RIHED Seminar on Linkages and Collaboration between Higher Education Institutions and Industry, 16 September, Danang, Vietnam.

SEAMEO RIHED, South-east Asian Ministers of Education Organisation-Regional Centre for Higher Education and Development. (2011). A study on quality assurance models in Southeast Asian countries: Towards a Southeast Asian quality assurance framework. Bangkok: SEAMEO RIHED.

SMU, Singapore Management University. (2014). University Profile. http://www.smu.edu.sg/smu/ about/university-information/quick-facts. Accessed October 9, 2014.

Sirisamphan, T. (2014). Vision and strategies for the development of higher education for the $21 \mathrm{st}$ century. Paper presented at the Development of Higher Education for the 21st Century, 3 February, Chiangrai, Thailand.

Thein, W. (2014). Linkage and collaboration between universities and industries in Myanmar. Paper presented at the Country paper presented at the SEAMEO RIHED Seminar on Linkages and Collaboration between Higher Education Institutions and Industry, 16 September, Danang, Vietnam.

Thinh, D. H., \& Phuong, H. T. M. (2011). Governance Reform in Higher Education of Vietnam. Asia Leadership Roundtable. 18 March Bangkok, Thailand. http://www.ied.edu.hk/apclc/ roundtable2011/paper.html. Accessed October 2, 2014.

Tuan, B. A. (2012). Vietnam country report. Paper presented at the Country paper presented at the SEAMEO RIHED Seminar on Internationalization of Higher Education in Southeast Asia, 22 September, Manila, The Philippines.

Varghese, N. V., \& Martin, M. (2013). Governance reform and university autonomy in Asia. Paris: UNESCO IIEP. 